\title{
The Competitiveness of the European ICT Industry
}

\author{
DIMITRIS PSYCHOYIOS \\ University of Piraeus *

\section{GEORGE DOTSIS} \\ Athens University*
}

\begin{abstract}
This paper investigates the international competitiveness of the European ICT sector. We use labour productivity, $R \& D$ expenses and trade performance as proxies of competitiveness. The empirical analysis of 39 countries between 1999 and 2004 confirms our main hypothesis that the EU is performing better in the ICT services industry relative to manufacturing. In general, the average EU production efficiency is larger in the services sector, than in manufacturing. The study has important policy implications. Appropriate policies should be implemented - especially in the ICT manufacturing sector - for making EU more competitive in "non- price factors", such as policies that facilitate the transformation of R\&D expenses into product innovation. There are clearly areas for improvement in the way R\&D is carried out in the ICT sector within the EU, with respect to both the allocation of $R \& D$ investment and the process of producing results from $R \& D$.
\end{abstract}

Keywords: Information technologies; Communications technologies Competitiveness; Economic growth; Labour productivity

JEL Classifications: G15, G18, J21, J24, L60, L80

\section{Introduction}

Competitiveness is considered a key aspect of modern economic policy and success. According to the European Union (EU), competitiveness is the degree to which a nation can, under free trade and fair market conditions, produce goods and services that meet the test of international markets, while simultaneously maintaining and expanding the real incomes of its people over the long-term. ${ }^{1}$ A number of indicators have been established in analysing the competitiveness of the EU economy from a sectoral perspective. Part of them (e.g. labour productivity and unit labour costs) can be considered as an intrinsic part of competitiveness, whereas others show

\footnotetext{
*Corresponding author, dpsycho@unipi.gr

(C) 2018 Dimitris Psychoyios and George Dotsis. Licensed under the Creative Commons Attribution Noncommercial 3.0 Licence (http://creativecommons.org/licenses/by-nc/3.0/) . Available at http: //rofea.org.

${ }^{1}$ European Competitiveness Report 2002: Competitiveness and Benchmarking (Enterprise Publications)
} 
how industries are performing in their market activities and international trade. Although the issue of competitiveness still remains highly elusive in the academic literature, it can be broadly defined as the effort to establish links between growth, balance of payments positions of an open economy and the factors that influence this process (Fagerberg, 1988).

Information and communication technology (ICT) sector is one of the key drivers for development and economic growth in the EU (see also Jalava and Pohjola, 2002, for the contribution of ICT use to economic growth). According to Eurostat data, the contribution of ICT to EU GDP represents approximately 5\%. Similarly, ICT is often argued to be the key determinant of the US productivity performance, see for example, Jorgenson et al. (2008). After the mid-1990s and almost until now, there is a significant divergence between the relative productivity levels of the EU and the US (van Ark et al., 2008). While the US economy experienced an increase in productivity growth, the corresponding productivity growth rate of European countries remained constant or even declined. Several studies indicate that the disappointing European growth performance can be attributed to the ineffective use of ICT (O’Mahony and van Ark, 2003; Matteucci, et al., 2005; Dahl, et al., 2011).

The issue of international competitiveness has been examined in previous research studies. Similar to our study, Halkos and Geremes (2007) investigate the importance of global competition in the ICT industry and its contribution to national economies, using, however, a sample of 50 ICT multinationals. According to their results, US and Japanese multinationals perform better, on average, than their European rivals (see also Bartlett and Ghoshal, 1987). On the other hand, Guerrieri and Meliciani (2005) investigate the determinants of international specialisation and international competitiveness focusing mainly in producer services, namely Financial, Communication, and Business services. They find that information and communication technologies have a significant impact on trade performance of the producer services under consideration (see also Lee et al., 2016).

The present study, taking into consideration the importance of the ICT sector, examines the international competitiveness of the European ICT sector using the following three key variables: Labour productivity, R\&D expenses and trade performance. Trade performance stands as the proxy for comparing the competitive position of each country in the Global ICT market. Labour productivity and $R \& D$ expenses can be tied to price competitiveness and technological competitiveness, respectively, and as such, they can be regarded as major determinants of the international competitiveness. Given the availability of the data, the motivation for the use of these variables is outlined in the ensuing discussion. The contribution of the paper is twofold: first, it demonstrates the importance of international competitiveness and its main drivers in the European ICT sector, and second, it produces important policy implications that can be used by the EU countries, in order for the EU to become more competitive, as far as the ICT sector is considered. Towards this end, the present study highlights the inefficiencies in the R\&D process regarding the ICT sector within the EU. There 
PSYCHOYIOS AND DOTSIS Competitiveness of the European ICT Industry

are evidence that both the allocation of $\mathrm{R} \& \mathrm{D}$ investment and the process of producing results from it, is inefficient.

Labour productivity has been considered as an important factor of competitiveness in an economy (Pitelis, 1998; Jorgenson and Stiroh, 1999; Gu and Ho, 2000; Delgado, Ketels, Porter and Stern, 2012). Productivity expresses the relationship between the output of goods and services and the various inputs required for production. It is directly connected to cost competitiveness, focusing on the efficiency of the productivity process in terms of lowering the cost per unit of output. It is widely accepted that productivity is a multi-dimensional concept and there are various measures that can be used conditional on the purpose of the analysis and data availability. There are two major productivity indicators. First, the labour productivity, which is defined as the ratio of real output to labour input, and second, the capital productivity, which is defined as the ratio of real output to the stock of fixed capital used in the production process. Table 1 shows the most popular measures of productivity that have been proposed in the literature (see Datta, Guthrie and Wright, 2005, and Schreyer and Pilat, 2001 for a review of labour productivity measures).

Table 1: Measures of Productivity

\begin{tabular}{|c|c|c|c|c|}
\hline \multicolumn{5}{|c|}{ Type of output measure } \\
\hline $\begin{array}{l}\text { Type of } \\
\text { output } \\
\text { measure: }\end{array}$ & Labour & Capital & Capital and labour & $\begin{array}{l}\text { Capital, labour and } \\
\text { intermediate Inputs } \\
\text { (energy, materials, } \\
\text { services) }\end{array}$ \\
\hline $\begin{array}{l}\text { Gross } \\
\text { output }\end{array}$ & $\begin{array}{l}\text { Labour productivity } \\
\text { (based on gross } \\
\text { output) }\end{array}$ & $\begin{array}{l}\text { Capital productivity } \\
\text { (based on gross } \\
\text { output) }\end{array}$ & $\begin{array}{l}\text { Capital - labour } \\
\text { MFP (based on } \\
\text { gross output) }\end{array}$ & $\begin{array}{l}\text { KLEMS multi-factor } \\
\text { productivity }\end{array}$ \\
\hline \multirow[t]{2}{*}{$\begin{array}{l}\text { Value- } \\
\text { added }\end{array}$} & $\begin{array}{l}\text { Labour productivity } \\
\text { (based on value- } \\
\text { added) }\end{array}$ & $\begin{array}{l}\text { Capital productivity } \\
\text { (based on value- } \\
\text { added) }\end{array}$ & $\begin{array}{l}\text { Capital-labour MFP } \\
\text { (based on value- } \\
\text { added) }\end{array}$ & - \\
\hline & \multicolumn{2}{|c|}{ Single factor productivity measures } & \multicolumn{2}{|c|}{ Multi-factor productivity (MFP) measures } \\
\hline
\end{tabular}

Notes: The most popular measures of productivity that have been proposed in the literature according to Schreyer and Pilat (2001)

The labour productivity and consequently price competitiveness may not be the sole factor for examining competitiveness. Although, according to classic economic theory, competitiveness, as measured by export success, is a function of prices, more recent studies show that "nonprice" factors of competitiveness, such us innovation and technological intensity, are equally important (see among others, Anderton, 1999; Blind and Jungmittag, 2005; Jung and Subramanian, 2017; Ioannidis and Schreyer, 1997). Towards this end, a number of studies have shown that technology is an important factor in the demand curves for trade, especially in the 
case of medium and higher-technology intensity sectors (see among others Griliches and Mairesse, 1984; Hall and Mairesse, 1995; Hall, Lotti and Mairesse, 2013). Following Temple (1999) and Griffith, Redding and Van Reenen (2004), we use R\&D expenses as a proxy of the effect of technology on productivity and competitiveness. Finally, there is a vast literature that correlates the performance of international competitiveness with the trade performance (see Buckley, Pass and Prescott, 1988, for an excellent review). Following Bernard et al. (2007) we use exports as a proxy of trade performance.

The rest of the paper is organised as follows: Section 2 describes the dataset. Section 3 presents the empirical findings regarding the interrelations among the competitiveness variables. Section 4 presents the results on the competitiveness of the EU ICT manufacturing and ICT services sectors. Section 5 contains the efficiency analysis, and Section 6 concludes.

\section{Descriptive Statistical Analysis}

In order to examine our hypotheses, we employ a panel dataset of the three macroeconomic variables under study (Labour Productivity, Exports and R\&D expenses) for $25 \mathrm{EU}$ countries. The data are collected and cross-checked from various sources, such as Datastream, World Bank, IMF, CIA, EUROSTAT, European Commission and local governments. The dataset consists of the simple annual growth rates of each variable between 2000 to 2004 (four observations per country). Growth rates were used for better comparisons between countries and regions. A brief description of the data and sources is given in Table 2 and Table 3 for the ICT manufacturing and services sector, respectively. For comparison purposes, we also include descriptive statistics, on aggregated level, for the Asia-Pacific countries, the Americas and the European Economic Area (EEA) ${ }^{2}$. The descriptive statistics employed, include: mean labour productivity growth (MLPG), mean exports growth (MEG) and mean R\&D expenses growth (MRDEG). Coefficients of variation (CV) for the growth rates are also reported as measures of stability.

\subsection{ICT Manufacturing Sector}

Table 2 reports the descriptive statistics for the manufacturing sector. The descriptive analysis indicates that Asian countries clearly outperform their global competitors in terms of magnitude and consistency in labour productivity growth. Countries from the Asia-Pacific region display the largest MLPG (34.95\%) followed by the Americas (18.17\%), and EU25 (16.24\%) and EEA

\footnotetext{
${ }^{2}$ The countries of the Asia-Pacific Region included in our sample are: Australia, China, Hong Kong, India, Japan, Singapore, South Korea, and Taiwan. Similarly, America's countries included in our study are: Canada, Mexico, and the United States. Finally, EEA countries included in our study are: Iceland, Norway, and Switzerland. Data for individual countries are shown in Appendix A.1.
} 
PSYCHOYIOS AND DOTSIS Competitiveness of the European ICT Industry

(0.96\%). The CV is smallest for the Asia-Pacific region, followed by EU25, the Americas and EEA, respectively. The remarkably small CV of the Asia-Pacific countries shows stability and consistency in productivity growth for the period under consideration. Within the EU25, smaller economies like Estonia, Malta and Lithuania, perform best in terms of stability and increase in labour productivity growth. Estonia has the largest MLPG (60.07\%), followed by Malta and Lithuania (47.38\% and 39.81\%, respectively). Netherlands and Cyprus have the smallest MLPG (5.41\% and 1.8\%, respectively) amongst EU25 countries. Eastern European countries have the smallest variation.

According to average growth in export performance, again, Asia-Pacific countries outperform most of their global competitors in terms of average growth (14.44\%). EU25 countries and the Americas follow with $2.98 \%$ and $-0.12 \%$, respectively. In the EU25, Estonia has the largest MEG (50.01\%), followed by the Czech Republic (36.09\%) and Hungary (22.1\%). Again, Eastern European countries show the smallest variation. Sweden performs worst amongst the EU25 with negative MEG (-8.84\%).

Turning our attention to R\&D expenses, EEA has the largest average growth (5.49\%) followed by the EU25 (2.82\%), Asia-Pacific (2.16\%) and the Americas (1.82\%). The large MRDEG in EEA is driven by Norway (4.44\%, see Appendix A.1). Within the EU25, countries from the former Eastern Bloc perform better, overall, than most of their western rivals. Lithuania has the most impressive growth in R\&D expenses (127.21\%) followed by Estonia, Hungary and Slovakia (117.9\%, 76.3\% and $76.1 \%$, respectively). Slovenia displays the smallest variation in growth rates (in absolute values). In the EU25, Poland has the worst performance with a negative MRDEG (-14.09\%).

\subsection{ICT Services Sector}

Table 3 reports the descriptive statistics for the Services sector. The Asia-Pacific countries display the largest MLPG (10.59\%), followed by the EU25 countries, EEA and the Americas (6.23\%, 4.86\% and 2.40\%, respectively). Amongst the main global competitors, EU25 now displays by far the smaller CV and STD. Within the EU25 countries, Malta has the largest MLPG (41.46\%), Latvia ranks second (32.8\%) and Greece third (27.49\%). United Kingdom and Austria have the smallest CVs (in absolute values). The worst performance, in terms of MLPG, is displayed by Slovakia. According to Table 3, although EU25 lags behind the AsiaPacific countries, it shows larger stability in the time period under consideration.

In terms of MEG, EU25 countries outperform both the Americas and the Asia-Pacific countries $(9,35 \%, 1.05 \%$ and $2.39 \%$, respectively). EU25 countries have also the most stable growth in exports. In the EU25 region, and in line with the results from the manufacturing sector, eastern countries perform better overall, than their western counterparts. The largest 
Review of Economic Analysis 10 (2018) 97-119

Table 2: Descriptive Statistics for ICT Manufacturing.

\begin{tabular}{|c|c|c|c|c|c|c|c|c|c|c|}
\hline & & \multicolumn{3}{|c|}{ Labour Productivity Growth } & \multicolumn{3}{|c|}{ Exports Growth } & \multicolumn{3}{|c|}{ R\&D expenses Growth } \\
\hline Countries & & Mean & STD & $\mathrm{CV}$ & Mean & STD & $\mathrm{CV}$ & Mean & STD & $\mathrm{CV}$ \\
\hline Austria & (AT) & 0.1089 & 0.1394 & 1.2803 & 0.1197 & 0.1730 & 1.4450 & 0.0465 & 0.0773 & 1.6632 \\
\hline Belgium & (BE) & 0.0841 & 0.1707 & 2.0303 & 0.0810 & 0.2696 & 3.3302 & 0.0520 & 0.1182 & 2.2739 \\
\hline Cyprus & (CY) & 0.0180 & 0.0688 & 3.8189 & 0.0869 & 0.2552 & 2.9372 & 0.1338 & 0.5369 & 4.0130 \\
\hline Czech Rep. & $(\mathrm{CZ})$ & 0.2722 & 0.2118 & 0.7781 & 0.3609 & 0.2148 & 0.5952 & 0.1761 & 0.1420 & 0.8064 \\
\hline Denmark & (DK) & 0.1095 & 0.1595 & 1.4569 & 0.0762 & 0.2485 & 3.2613 & 0.1392 & 0.1146 & 0.8235 \\
\hline Estonia & (EE) & 0.6077 & 0.7235 & 1.1906 & 0.5001 & 0.9828 & 1.9652 & 1.1785 & 2.0445 & 1.7348 \\
\hline Finland & $(\mathrm{FI})$ & 0.1488 & 0.2046 & 1.3746 & 0.0607 & 0.2658 & 4.3796 & 0.0903 & 0.0966 & 1.0700 \\
\hline France & (FR) & 0.1716 & 0.1747 & 1.0182 & -0.037 & 0.2015 & -5.4505 & 0.0395 & 0.0363 & 0.9212 \\
\hline Germany & (DE) & 0.1820 & 0.2465 & 1.3543 & 0.0770 & 0.1993 & 2.5901 & 0.0157 & 0.0874 & 5.5821 \\
\hline Greece & (GR) & 0.0754 & 0.1604 & 2.1287 & 0.1387 & 0.4441 & 3.2027 & 0.1248 & 0.1444 & 1.1572 \\
\hline Hungary & (HU) & 0.2430 & 0.2259 & 0.9299 & 0.2217 & 0.2908 & 1.3116 & 0.7630 & 1.4667 & 1.9224 \\
\hline Ireland & (IE) & 0.3582 & 0.4332 & 1.2093 & 0.0098 & 0.2919 & 29.7831 & -0.0485 & 0.1730 & -3.5651 \\
\hline Italy & (IT) & 0.1596 & 0.1450 & 0.9089 & 0.0072 & 0.1785 & 24.8763 & 0.0143 & 0.0476 & 3.3401 \\
\hline Latvia & (LV) & 0.3838 & 0.3331 & 0.8677 & 0.1109 & 0.0144 & 0.1300 & - & - & - \\
\hline Lithuania & (LT) & 0.3981 & 0.2614 & 0.6567 & 0.1108 & 0.1284 & 1.1588 & 1.2721 & 2.5714 & 2.0213 \\
\hline Luxembourg & $(\mathrm{LU})$ & 0.1754 & 0.2214 & 1.2627 & 0.0258 & 0.4038 & 15.6646 & 0.2950 & 0.6179 & 2.0944 \\
\hline Malta & (NL) & 0.4738 & 0.7140 & 1.5069 & 0.0729 & 0.4042 & 5.5449 & 0.0473 & 0.5042 & 10.6717 \\
\hline Netherlands & $(\mathrm{NO})$ & 0.0541 & 0.1780 & 3.2928 & 0.0620 & 0.2299 & 3.7069 & 0.0074 & 0.0793 & 10.7469 \\
\hline Poland & (PL) & 0.1319 & 0.2347 & 1.7799 & 0.1987 & 0.1065 & 0.5362 & -0.1409 & 0.1979 & -1.4044 \\
\hline Portugal & (PT) & 0.2070 & 0.3716 & 1.7957 & 0.1703 & 0.1438 & 0.8447 & 0.0671 & 0.1045 & 1.5577 \\
\hline Slovakia & (SK) & 0.2185 & 0.2856 & 1.3071 & 0.2063 & 0.2010 & 0.9741 & 0.7610 & 1.6956 & 2.2281 \\
\hline Slovenia & (SI) & 0.2673 & 0.2089 & 0.7814 & 0.0846 & 0.1108 & 1.3102 & 0.2721 & 0.1331 & 0.4892 \\
\hline Spain & (ES) & 0.1044 & 0.1976 & 1.8936 & 0.0304 & 0.1498 & 4.9332 & 0.0200 & 0.1869 & 9.35 \\
\hline Sweden & (SE) & 0.2293 & 0.6760 & 2.9481 & -0.088 & 0.2256 & -2.5537 & 0.0711 & 0.2002 & 2.8151 \\
\hline U.K. & (GB) & 0.1845 & 0.3757 & 2.0365 & -0.021 & 0.1958 & -9.2582 & 0.0079 & 0.0908 & 11.4598 \\
\hline EU25 & & 0.1624 & 0.2168 & 1.3349 & 0.0298 & 0.2026 & 6.7973 & 0.0282 & 0.0708 & 2.5077 \\
\hline EEA & & 0.0096 & 0.0605 & 6.2914 & -0.012 & 0.1491 & -12.175 & 0.0549 & 0.2028 & 3.6947 \\
\hline Asia-Pacific & & 0.3495 & 0.3120 & 0.8927 & 0.1444 & 0.3690 & 2.5553 & 0.0216 & 0.1791 & 8.3129 \\
\hline Americas & & 0.1817 & 0.2872 & 1.5810 & -0.001 & 0.3109 & -264.59 & 0.0182 & 0.2689 & 14.8139 \\
\hline
\end{tabular}

Notes: To remove non-stationarities and allow comparisons between counties, we concentrate on growth rates. The statistics are reported for all countries separately, as well as on aggregated level for the EU25, Asia-Pacific countries, the Americas and EEA and span the period from 2000 to 2004. The descriptive statistics employed include: mean labour productivity growth, mean exports growth and mean R\&D expenses growth. Standard deviation (STD) and coefficient of variation (CV) for the growth rates are also reported as measures of stability. 
PSYCHOYIOS AND DOTSIS Competitiveness of the European ICT Industry

growth is displayed by Poland (37.59\%), followed by Hungary, Slovakia and the Czech Republic $(26.11 \%, 22.02 \%$ and $21.09 \%$, respectively). The worst performance is displayed by Greece with a decline of $-13.80 \%$.

With respect to MRDEG, the Americas have the largest growth rate (19.2\%), with EU25 and EEA in the second and third position (10.71\% and $8.93 \%$, respectively). Although data is incomplete for the Asia-Pacific countries, we note a negative growth rate (-5.48\%). EU25 displays the most stable growth in R\&D expenses. In the EU, the highest MRDEG is displayed by Estonia (75.47\%) and is followed by the Czech Republic and Slovakia (68.62\% and 56.59\%, respectively). Austria and Greece have the smallest CVs. Sweden and Poland perform worst with negative MRDEGs ( $-5.93 \%$ and -7.64 , respectively). EU25 countries appear to perform well in terms of R\&D growth, though behind the Americas.

Overall, the descriptive analysis shows that the EU is performing better in the ICT services industry relative to manufacturing. It appears that the emergence of countries from the AsiaPacific region (e.g. China) in the global market, affected the EU more on the manufacturing sector. One must also keep in mind that part of the EU competitiveness in services can be attributed to the fact that export trade is mainly within the region. In contrast, the impact of China and South Korea in the services sector is probably larger for the Americas and the neighbouring countries, such as Japan.

\section{Factor Analysis}

In order to study the interrelations among the competitiveness variables under study and identify any hidden underlying structures (i.e. group of countries), we employ principal component analysis (PCA). PCA can be used for reducing dimensionality in a dataset, while retaining those characteristics of the dataset that contribute most to its variance, by keeping lower-order principal components and ignoring higher-order ones. The idea is that such loworder components often contain the "most important" aspects of the data (Jolliffe, 1986). In this manner, we also include two more variables in the analysis: the total output, as measured by value added, and the world share of ICT exports for each country.

Due to data limitations, the analysis is performed only for the Manufacturing sector, for the complete period from 2000 to 2003 (four years) and for each individual year. In the first case, we have also included some major Asia-Pacific and Americas' countries, for comparison purposes. In all cases studied, the first three factors explain more than $95 \%$ of the total variation, while only the first two of them explain an adequate part of the total variation (almost $80 \%$ ). 
Review of Economic Analysis 10 (2018) 97-119

Table 3: Descriptive Statistics for ICT Services.

\begin{tabular}{|c|c|c|c|c|c|c|c|c|c|c|}
\hline \multirow[b]{2}{*}{ Countries } & & \multicolumn{3}{|c|}{$\begin{array}{c}\text { Labour Productivity } \\
\text { Growth }\end{array}$} & \multicolumn{3}{|c|}{ Exports Growth } & \multicolumn{3}{|c|}{ R\&D expenses Growth } \\
\hline & & Mean & STD & $\mathrm{CV}$ & Mean & STD & $\mathrm{CV}$ & Mean & STD & $\mathrm{CV}$ \\
\hline Austria & $(\mathrm{AT})$ & 0.1037 & 0.0337 & 0.3251 & 0.0717 & 0.2177 & 3.0364 & 0.1469 & 0.0482 & 0.3279 \\
\hline Belgium & $(\mathrm{BE})$ & 0.0403 & 0.0332 & 0.8237 & 0.0582 & 0.1777 & 3.0566 & -0.0218 & 0.1896 & -8.6869 \\
\hline Cyprus & $(\mathrm{CY})$ & - & - & - & - & - & - & 0.1030 & 0.1323 & 1.2838 \\
\hline Czech Rep. & $(\mathrm{CZ})$ & 0.0954 & 0.1176 & 1.2329 & 0.2109 & 0.3172 & 1.5044 & 0.6862 & 0.7634 & 1.1125 \\
\hline Denmark & (DK) & 0.0631 & 0.0871 & 1.3796 & - & -- & - & 0.1928 & 0.1340 & 0.6949 \\
\hline Estonia & $(\mathrm{EE})$ & 0.1326 & 0.1993 & 1.5029 & - & - & - & 0.7547 & 1.5520 & 2.0564 \\
\hline Finland & (FI) & 0.1214 & 0.0802 & 0.6604 & 0.0253 & 0.6610 & 26.1271 & 0.2604 & 0.2410 & 0.9255 \\
\hline France & (FR) & 0.0584 & 0.0724 & 1.2409 & 0.1310 & 0.2500 & 1.9083 & 0.1716 & 0.1732 & 1.0097 \\
\hline Germany & (DE) & 0.0635 & 0.1482 & 2.3329 & 0.1662 & 0.2813 & 1.6928 & 0.0440 & 0.0702 & 1.5946 \\
\hline Greece & (GR) & 0.2749 & 0.2562 & 0.9320 & -0.1380 & 0.1167 & -0.8460 & 0.4097 & 0.2832 & 0.6913 \\
\hline Hungary & (HU) & 0.0490 & 0.0640 & 1.3070 & 0.2611 & 0.3625 & 1.3884 & 0.3196 & 0.2344 & 0.7334 \\
\hline Ireland & (IE) & 0.1177 & 0.1360 & 1.1549 & 0.1785 & 0.2843 & 1.5931 & 0.3687 & 0.3585 & 0.9724 \\
\hline Italy & (IT) & 0.0523 & 0.0423 & 0.8086 & 0.0346 & 0.2700 & 7.8151 & 0.1337 & 0.3713 & 2.7774 \\
\hline Latvia & $(\mathrm{LV})$ & 0.3280 & 0.3242 & 0.9883 & - & - & - & 0.4285 & 0.3970 & 0.9266 \\
\hline Lithuania & (LT) & 0.1430 & 0.2058 & 1.4390 & - & - & - & - & - & - \\
\hline Luxembourg & $g(L U)$ & -0.0368 & 0.0831 & -2.2567 & -0.0061 & 0.2366 & -38.7950 & -0.0079 & 0.1019 & -12.8935 \\
\hline Malta & $(\mathrm{NL})$ & 0.4146 & 0.4617 & 1.1137 & - & - & - & - & - & - \\
\hline Netherlands & $(\mathrm{NO})$ & 0.0102 & 0.0636 & 6.2305 & 0.0754 & 0.3651 & 4.8411 & 0.3592 & 0.5972 & 1.6625 \\
\hline Poland & $(\mathrm{PL})$ & 0.1228 & 0.1447 & 1.1786 & 0.3759 & 0.5232 & 1.3921 & -0.0764 & 0.4678 & -6.1249 \\
\hline Portugal & (PT) & 0.0754 & 0.1472 & 1.9531 & 0.0087 & 0.2054 & 23.6805 & 0.1723 & 0.2637 & 1.5304 \\
\hline Slovakia & (SK) & -0.0724 & 0.2022 & -2.7918 & 0.2202 & 0.3544 & 1.6092 & 0.5659 & 1.3792 & 2.4374 \\
\hline Slovenia & (SI) & 0.0364 & 0.1040 & 2.8597 & - & - & - & - & - & - \\
\hline Spain & (ES) & 0.1190 & 0.1215 & 1.0205 & 0.0514 & 0.1007 & 1.9585 & 0.4543 & 0.7719 & 1.6989 \\
\hline Sweden & $(\mathrm{SE})$ & 0.0291 & 0.1148 & 3.9461 & 0.0905 & 0.2320 & 2.5645 & -0.0593 & 0.2033 & -3.4266 \\
\hline U.K. & (GB) & 0.0752 & 0.0234 & 0.3111 & 0.0606 & 0.0855 & 1.4116 & 0.0964 & 0.1653 & 1.7148 \\
\hline EU 25 & & 0.0623 & 0.0602 & 0.9657 & 0.0935 & 0.1756 & 1.8784 & 0.1071 & 0.0710 & 0.6632 \\
\hline EEA & & 0.0486 & 0.0638 & 1.3136 & 0.1105 & 0.6713 & 6.0762 & 0.0893 & 0.0615 & 0.6894 \\
\hline Asia-Pacific & & 0.1059 & 0.1706 & 1.6107 & 0.0239 & 0.2578 & 10.7733 & -0.0548 & 0.0569 & -1.0384 \\
\hline Americas & & 0.0240 & 0.1260 & 5.2536 & 0.0105 & 0.1495 & 14.2749 & 0.1920 & 0.3090 & 1.6096 \\
\hline
\end{tabular}

Notes: To remove non-stationarities and allow comparisons between countries, we concentrate on growth rates. The statistics are reported for all countries separately, as well as on aggregated level for the EU25, Asia-Pacific countries, the Americas and EEA and span the period from 2000 to 2004. The descriptive statistics employed include: mean labour productivity growth, mean exports growth and mean R\&D expenses growth. Coefficients of variation (CV) and standard deviation (STD) for the growth rates are also reported as measures of stability. 


\section{PSYCHOYIOS AND DOTSIS Competitiveness of the European ICT Industry}

An effective way of interpreting and depicting the PCA results is to depict scatterplots, using the loadings of the two first factors as co-ordinates (Figure 1 and 2$)^{3}$.

Despite the limited number of observations, the following conclusions can be drawn on the basis of PCA. First, the Baltic Countries, Estonia (EE), Latvia (LV) and Lithuania (LT), tend to distinguish themselves from the remaining, with pairs forming distinct clusters. Second, countries in southern Europe, Spain (ES), Portugal (PT), Cyprus (CY) and Greece (GR) follow similar patterns during almost the whole period. Third, Sweden (SE), Ireland (IE) and Finland (FI) also show signs of forming a distinct cluster. Finally, Figure 1, where we include more countries in the analysis, shows that on one hand, India (IN), South Korea (SG) and China (CN) tend to form a cluster, and on the other hand, the European Union countries tend to form a distinct one. The above distinguished clusters suggest asynchronies in business cycles, but also in the key variables determining competitiveness.

Figure 1: Factor Map of loadings for the first two principal components, $2000-2003$

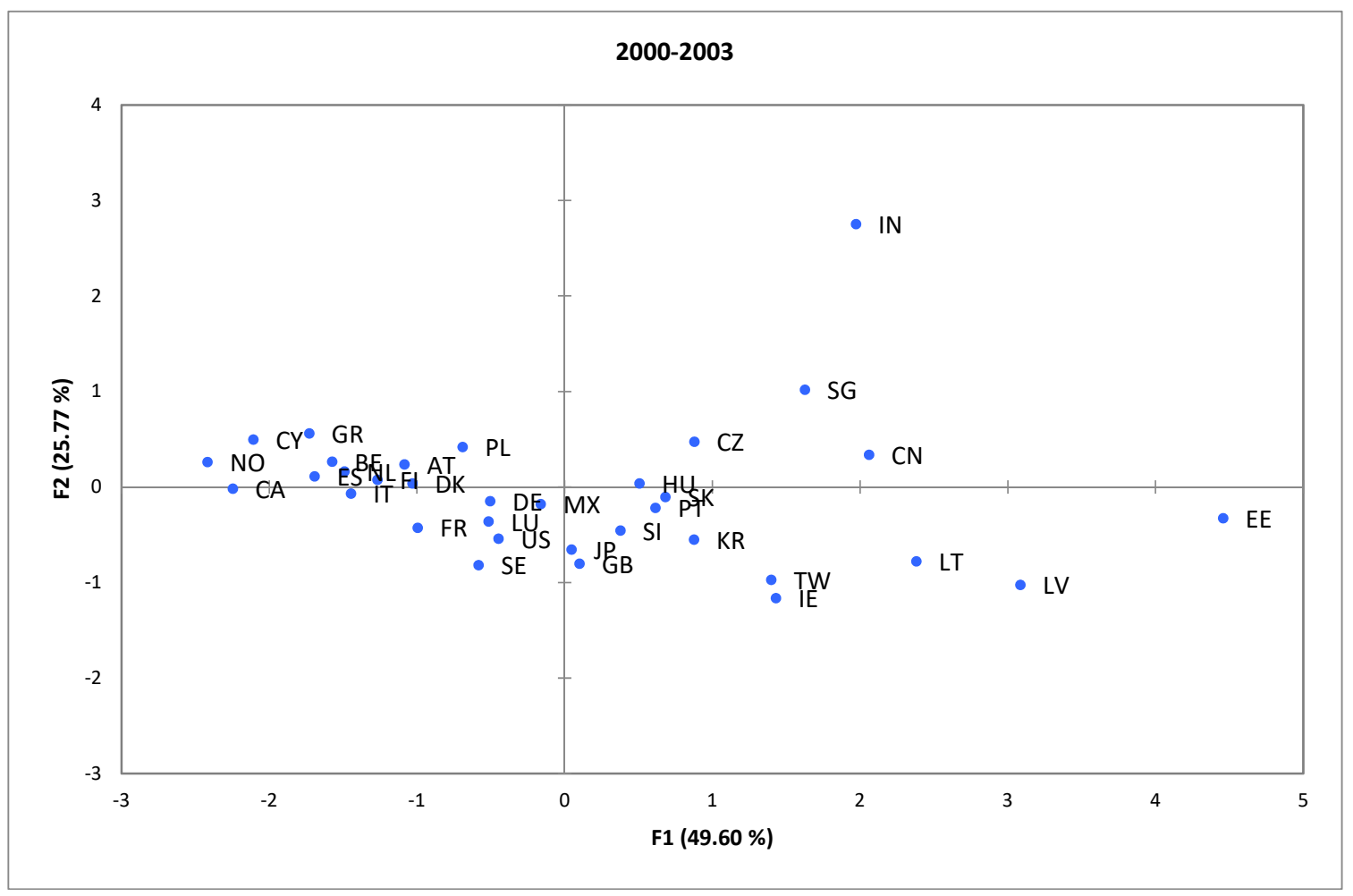

\footnotetext{
${ }^{3}$ The additional countries included in Figure 1 are: China (CN), India (IN), Japan (JP), Mexico (MX), Singapore (SG), South Korea (KR), Taiwan (TW), USA (US).
} 
Review of Economic Analysis 10 (2018) 97-119

Figure 2: Factor Map of loadings for the first two principal components, for the years 2000, 2001, 2002, 2003, respectively

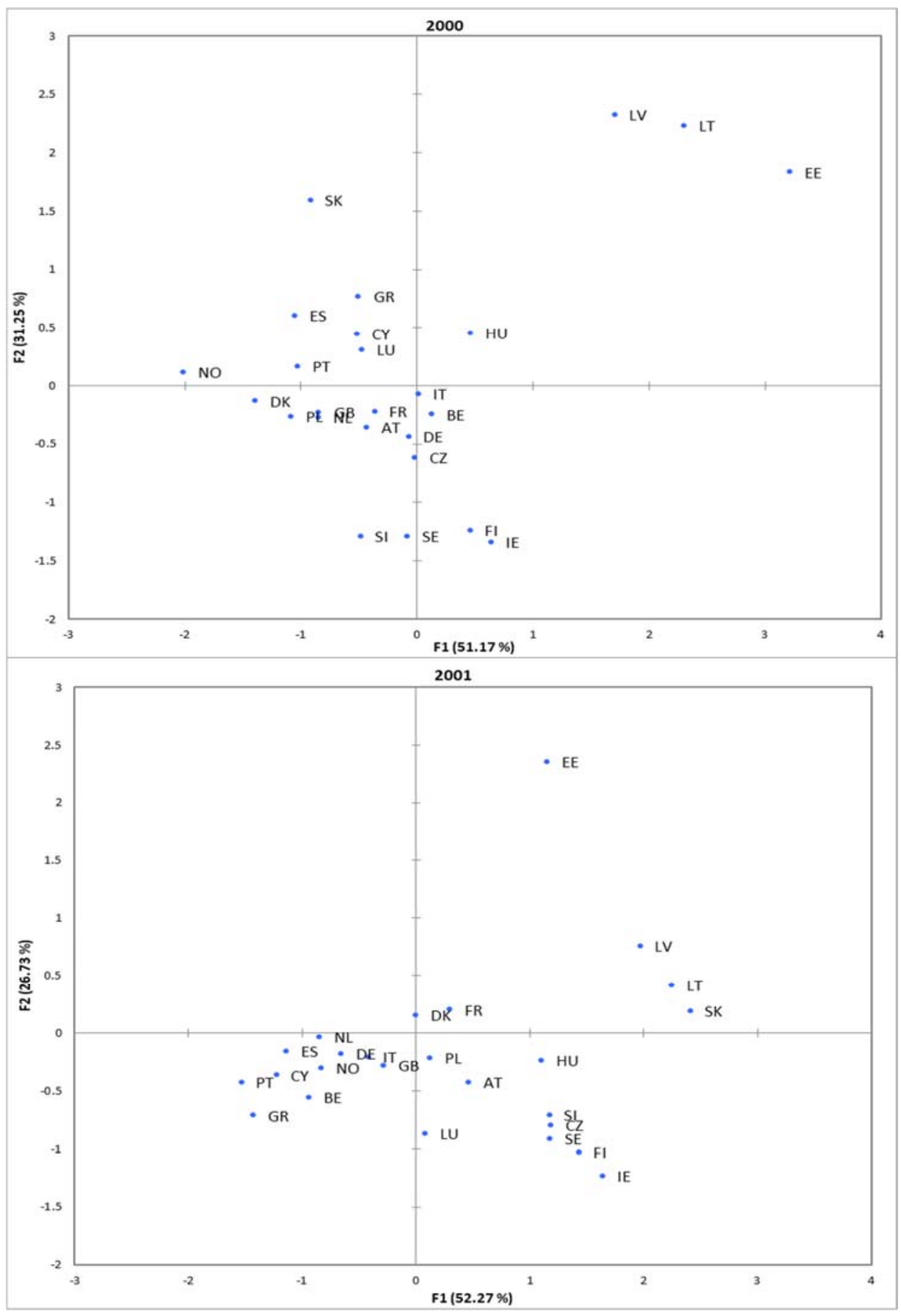


PSYCHOYIOS AND DOTSIS Competitiveness of the European ICT Industry

Figure 2 continued

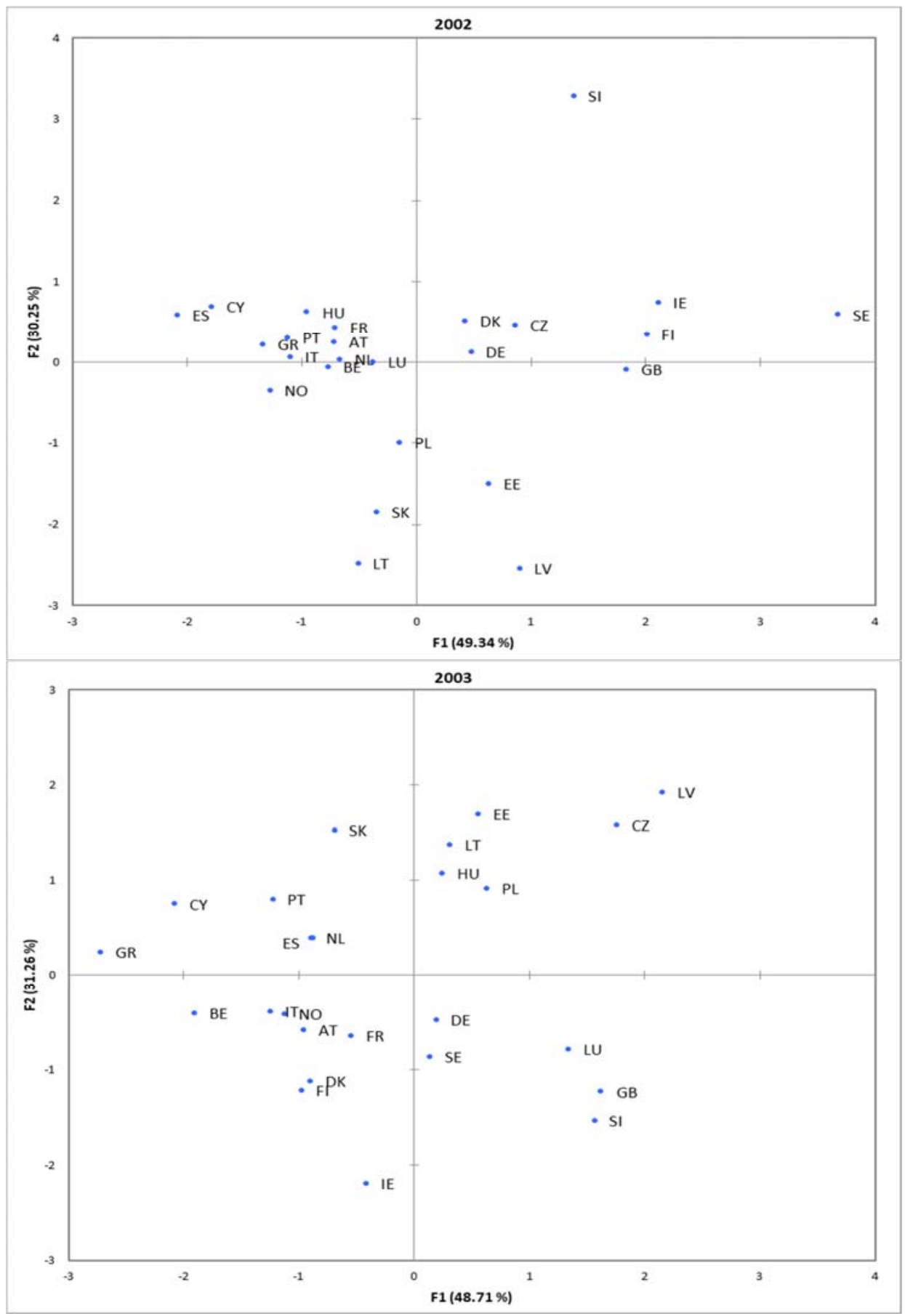

107 


\section{Panel data analysis}

An analysis of the determinants of the competitiveness of the European ICT industry is presented in this section. As such, we apply panel regression analysis on the trade performance of the EU ICT manufacturing and ICT services sectors, respectively. The purpose of this analysis is to confirm the empirical validity of the theoretical relationships with respect to competitiveness between the key variables used in this paper.

For the purposes of the analysis, the sample was divided into two sub-samples. The first contains countries of the European Union and the second contains countries outside the EU. The two sub-samples were examined independently, so that any possible differences in the significance of the determinants of competitiveness between the EU and the rest of the world could be examined. After accounting for missing values, the EU sub-sample contains 24 countries (no data were available for R\&D expenditures in Latvia) and 4 years (2000-2003). The model for the other sub-sample incorporates 5 countries, for the same period, and data for R\&D expenditures were available only for Canada, Japan, South Korea, Norway and the United States. As in Sections 2 and 3, we use simple annual growth rates.

Exports are used as a proxy of measuring competitiveness and they are regressed against labour productivity per employee and against research \& development expenditures, so that the basic model in our analysis is the following:

$$
E_{i t}=a_{i}+\beta_{1} L_{i t}+\beta_{2} R_{i t}+\varepsilon_{i t}
$$

where $E_{i t}$ denotes the exports of country $i$ at period $t, L_{i t}$ is the labour productivity of country $i$ at period $t, R_{i t}$ denotes the R\&D expenditures of country $i$ at period $t$ and $\varepsilon_{i t}$ denotes the residuals of the regression.

An important advantage of panel models is that they allow great flexibility in modelling differences in behaviour across either the cross-section or period dimensions, or both. This means that when cross-section or period-specific effects are present, they can be eliminated through the use of feasible techniques, so that the model captures the true relationship between the dependent and independent variables. These models can be tackled using either pooled OLS, fixed effects or random effects. Although we assume statistical independence between $a_{i}$ and $\varepsilon_{i t}$, the allowance of any kind of correlation between $a_{i}, L_{i t}$ and $R_{i t}$ will determine if we are going to use a fixed-effects or a random-effects approach. Following a fixed-effects approach, means that we are going to allow for such correlation, while a random-effects approach assumes that $a_{i}$ is not correlated with regressors. It would be reasonable to suggest that the unobserved timeinvariant variables that have an impact on $E_{i t}$ are correlated with $L_{i t}$ and $R_{i t}$ of time-varying regressors and therefore, the use of a fixed-effects approach is appropriate and statistically sound. We also confirm this by running the fixed-effects and random-effects regressions and 
PSYCHOYIOS AND DOTSIS Competitiveness of the European ICT Industry

Table 4: Panel Estimation Results (ICT Manufacturing).

\begin{tabular}{lcc}
\hline & EU & Other countries \\
\hline Constant & 0,0761 & $-0,1520$ \\
& $(0,0260)$ & $(0,0460)$ \\
Labour productivity per employee & 0,2014 & 0,4885 \\
& $(0,1169)$ & $(0,1600)$ \\
R\&D expenses & $-0,1188$ & 0,7161 \\
& $(0,0547)$ & $(0,1796)$ \\
Adjusted R-squared & 0,4527 & 0,4812 \\
Durbin-Watson statistic & 2,3167 & 3,2717 \\
F-statistic & 3,7477 & 3,9368 \\
\hline
\end{tabular}

Notes: The table summarizes the results of Panel Estimation for both samples for the ICT Manufacturing industry. All coefficients are significant at the 10\% level. HAC Standard errors are given in parentheses

conducting a Hausman test, which suggests that a random-effects estimator would be inconsistent. Both cross-section and period-specific fixed effects have been incorporated to the models.

Table 4 summarizes the results of Panel Estimation for both samples for the ICT Manufacturing industry. Firstly, labour productivity per employee appears to have a much more significant effect on exports for the 'other countries' in the world, than it does for the EU countries. Secondly, R\&D expenditures appear to have a negative impact on exports for the EU, whereas for 'other countries' it has a significantly high positive impact. This appears at odds, since one would expect a positive relationship. A plausible explanation of the latter result is that it is not the R\&D expenses per se that matter, but whether R\&D produces results in innovation and product quality (Carlin, Glyn, and Van Reenen, 2001). However, it should be noted that R\&D expenses may not have an immediate effect and therefore may impact with some hysteresis the input-output relationship and therefore productivity (Rouvinen, 2002) ${ }^{4}$. The negative sign may also indicate that the EU countries are less competitive than their main peers in the ICT manufacturing. Finally, both models have a satisfactory adjusted R-squared statistic, a fact that can be partially attributed to the inclusion of cross-section and/or period effects to the model. Notably, the R-squared statistic is very close between samples. The Durbin-Watson statistic suggests lack of first-order autocorrelation in the disturbances.

\footnotetext{
${ }^{4}$ We also used lagged R\&D expenses, but the results were not robust due to the short time period under consideration.
} 
Table 5 presents the results of panel estimation for the EU and 'other counties' samples for the ICT services sector. As is the case for the ICT Manufacturing sector, the results reveal differences between the two samples. Firstly, labour productivity per employee appears to have a significant negative effect on exports in the EU, whereas for the 'other countries' it has a significant positive effect. The puzzling result for the world and EU is most likely due to the very limited dataset available for the services sector. It could also be produced by the fact that labour productivity is not measured in terms of unit labour cost. Finally, it is possible that labour productivity by itself, if not properly mixed with appropriate $\mathrm{R} \& \mathrm{D}$ and capital expenditure, is not enough to produce higher exports. R\&D expenses now appear to have a positive relationship with exports, but $R \& D$ expenses have a more significant effect on exports in the other countries sample, than it has in the EU sample.

Table 5: Panel Estimation Results (ICT Services).

\begin{tabular}{lcc}
\hline & EU & Other countries \\
\hline Constant & 0,0902 & 0,0919 \\
& $(0,0126)$ & $(0,0210)$ \\
Labour productivity per employee & $-0,4766$ & 0,5347 \\
& $(0,0758)$ & $(0,1673)$ \\
R\&D expenses & 0,0252 & 0,3538 \\
& $(0,0010)$ & $(0,1170)$ \\
Adjusted R-squared & 0,9124 & 0,1574 \\
Durbin-Watson statistic & 2,5273 & 1,8229 \\
F-statistic & 34,6147 & 1,5915 \\
\hline
\end{tabular}

Notes: The table presents the results of panel estimation for the EU and other countries samples for the ICT services sector. All coefficients are significant at the $10 \%$ level. HAC Standard errors are given in parentheses.

\section{Efficiency Analysis}

In this section, we employ productive efficiency analysis for quantifying the relative success and productivity of economic units. The productivity of an economic unit is typically defined as the ratio of its output to its input and is a function of many factors such as technology, the environment, efficiency, etc. One of the most widely used measures of productivity performance is efficiency, which compares realised and optimal levels of outputs and inputs. If this comparison is made in terms of production possibilities, then "technical" efficiency is measured, while a comparison in terms of a behavioural goal (e.g. cost, revenue, profit) 
PSYCHOYIOS AND DOTSIS Competitiveness of the European ICT Industry

measures "economic" efficiency. Measuring efficiency is very useful since it allows us to evaluate and compare the success and potential of individual economic units or countries, production scenarios, organisational structures, management strategies, etc. Efficiency analysis can identify and measure sources of successful performance and therefore can be utilised in policy planning and allocation of resources. The methodological approaches in efficiency analysis include a wide range of econometric and mathematical programming techniques (Fried, Lovell and Schmidt, 1993). In the present analysis, we employ Data Envelopment Analysis (DEA), a popular and widely used mathematical programming technique which has the advantage of making minimal assumptions about the data and production function while allowing rich interpretation.

The standard DEA approach makes some assumptions about constant returns to scale, the strong disposability of inputs and outputs, and convexity of the set of feasible input/output combinations. Although all of these assumptions can be relaxed, in practice this is rarely done for the last two in practice. DEA assumes a deterministic frontier, although it is possible to modify it for the stochastic case. The efficiency measures are distances to an empirical production frontier and the values are calculated on the basis of standard Pareto efficiency. No assumption has to be made about the production function, because the frontier is the observed best practice of the raw dataset available. Efficiency scores are calculated by solving an "envelopment" problem via linear programming. Intuitively, this involves measuring the efficiency of a production unit by finding a set of weights to apply to its inputs and outputs.

In order to examine the efficiency of output product in relation to the input, we consider added value in constant prices as the output and labour hours and R\&D expenses as the input. The R\&D expenses have been converted to 1999 constant prices by using the total ICT Manufacturing and Services deflators. Since we do not consider capital expenditures, the analysis does not formally examine productive efficiency, but rather investigates the relative performance of each country with respect to the ability to exploit labour and R\&D for a given output. The analysis is carried out only for those countries for which both variables are available. In contrast to traditional neoclassical models, DEA does not require the definition of a specific form of an underlying production function that characterises the existing technology, such as the Cobb-Douglas production function. The best countries receive an efficiency score one $(100 \%)$, while the other ones receive smaller scores depending on their relative performance. In the analysis, we employ the cost minimization version of DEA, that is, efficiency is examined in terms of efficient use of input variables for a given level of output and we assume constant returns to scale. The DEA analysis is implemented separately for each year and then we study the intertemporal behaviour of the scores. Given the availability of the data, we also include the major global competitors of the EU, mainly for comparison purposes (there are no sufficient data for India and China). 
Table 6 reports the rankings of the countries according to the DEA methodology for the manufacturing sector. Ireland and Luxemburg are on the frontier from 1999 to 2003, thus suggesting that they use their resources in the most efficient way. Greece is on the frontier for 2000 but deteriorates substantially in 2003. Czech Republic displays a sudden increase in efficiency from 1999 onwards. France and Germany perform moderate for 1999 and 2000, but their performance deteriorates substantially in the following years, especially in 2003. For most of the EU countries, their performance deteriorates after 1999. Most New Member States are below EU average scores. The EU, compared to the US, performs worst for all years under consideration, with the exception of 2003. In relation to Japan, the EU performs worst in all years. According to the aforementioned analysis, the EU is lagging behind in terms of efficient use of its resources. The average EU score (48.9\%) suggests that the EU could use a much smaller fraction of its resources to attain the same outcome, if it was fully efficient.

Table 7 presents the results for the ICT services sector. Belgium, Poland and Luxembourg are on the frontier for all years. Ireland is also on the frontier, with the exception of 1999. In contrast to the results from the manufacturing industry, now more countries appear to produce efficiently. Still, most of the New Member States are below the EU average. The EU performs better than Canada, Japan and South Korea. Still the EU underperforms comparing to the United States, but to a lesser extent relative to the case of the manufacturing industry. In 1999, the EU is ranked above the United States, but loses pace during the subsequent years.

Ireland and Luxemburg appear to be an exceptional case within the EU, since they perform efficiently both in the manufacturing and the services industry. Nevertheless, the apparent efficiency of Luxemburg does not translate into exports growth. Belgium and Poland perform efficiently in the ICT service industry. The large economies of the EU, France, Germany and Italy are by far more efficient in the ICT services than in the ICT manufacturing. In contrary, the performance of the UK does not differentiate much between the two sectors.

\section{Conclusions}

Overall, the descriptive analysis shows that the EU is performing better in the ICT services industry than in manufacturing. In the manufacturing sector, the EU is lagging behind China, which shows an extraordinary productivity and exports growth. The EU also underperforms in comparison to other Asia-Pacific countries, such as India, Singapore, South Korea and Taiwan. The small export growth in the EU is largely due to the negative export growth of France and Sweden. High export growth is displayed by Estonia and the Czech Republic. In the services sector, the EU, along with the US, still retains the largest portion of the total ICT services production. However, the EU displays a larger average labour productivity and exports growth in comparison to the US. South Korea is growing fast, but represents a small fraction of the 
PSYCHOYIOS AND DOTSIS Competitiveness of the European ICT Industry

Table 6: Efficiency Scores - ICT Manufacturing Sector.

\begin{tabular}{|c|c|c|c|c|c|}
\hline Country & 1999 & 2000 & 2001 & 2002 & 2003 \\
\hline Austria & $100.00 \%$ & $96.74 \%$ & $97.20 \%$ & $69.72 \%$ & $55.26 \%$ \\
\hline Belgium & $68.99 \%$ & $62.63 \%$ & $46.46 \%$ & $30.66 \%$ & $17.59 \%$ \\
\hline Cyprus & $30.75 \%$ & $11.98 \%$ & $10.10 \%$ & $4.68 \%$ & $2.43 \%$ \\
\hline Czech & $17.15 \%$ & $100.00 \%$ & $100.00 \%$ & $100.00 \%$ & $100.00 \%$ \\
\hline Denmark & $61.89 \%$ & $44.07 \%$ & $39.27 \%$ & $29.04 \%$ & $18.63 \%$ \\
\hline Estonia & $15.69 \%$ & $28.14 \%$ & $18.93 \%$ & $18.93 \%$ & $16.65 \%$ \\
\hline Finland & $100.00 \%$ & $100.00 \%$ & $87.37 \%$ & $51.29 \%$ & $29.33 \%$ \\
\hline France & $74.71 \%$ & $65.02 \%$ & $65.69 \%$ & $43.01 \%$ & $28.91 \%$ \\
\hline Germany & $60.11 \%$ & $52.86 \%$ & $42.34 \%$ & $32.66 \%$ & $23.43 \%$ \\
\hline Greece & $87.96 \%$ & $100.00 \%$ & $98.49 \%$ & $81.11 \%$ & $54.04 \%$ \\
\hline Hungary & $39.00 \%$ & $30.13 \%$ & $38.33 \%$ & $33.27 \%$ & $25.95 \%$ \\
\hline Ireland & $100.00 \%$ & $100.00 \%$ & $100.00 \%$ & $100.00 \%$ & $100.00 \%$ \\
\hline Italy & $45.03 \%$ & $43.23 \%$ & $42.60 \%$ & $28.00 \%$ & $22.34 \%$ \\
\hline Lithuania & $19.71 \%$ & $13.60 \%$ & $17.19 \%$ & $29.88 \%$ & $24.06 \%$ \\
\hline Luxembourg & $100.00 \%$ & $100.00 \%$ & $100.00 \%$ & $100.00 \%$ & $100.00 \%$ \\
\hline Netherlands & $54.94 \%$ & $42.77 \%$ & $33.90 \%$ & $21.86 \%$ & $14.65 \%$ \\
\hline Poland & $31.43 \%$ & $35.04 \%$ & $40.84 \%$ & $41.86 \%$ & $39.57 \%$ \\
\hline Portugal & $38.42 \%$ & $39.70 \%$ & $45.98 \%$ & $53.60 \%$ & $55.01 \%$ \\
\hline Slovakia & $19.53 \%$ & $9.04 \%$ & $12.21 \%$ & $14.67 \%$ & $14.59 \%$ \\
\hline Slovenia & $28.17 \%$ & $28.12 \%$ & $29.39 \%$ & $24.17 \%$ & $22.12 \%$ \\
\hline Spain & $47.32 \%$ & $39.64 \%$ & $51.28 \%$ & $23.08 \%$ & $20.44 \%$ \\
\hline Sweden & $69.87 \%$ & $58.02 \%$ & $13.84 \%$ & $20.07 \%$ & $15.79 \%$ \\
\hline UK & $71.90 \%$ & $62.38 \%$ & $51.42 \%$ & $52.60 \%$ & $42.87 \%$ \\
\hline EU & $55.76 \%$ & $54.92 \%$ & $51.43 \%$ & $43.66 \%$ & $36.68 \%$ \\
\hline Norway & $67.72 \%$ & $44.44 \%$ & $33.36 \%$ & $20.61 \%$ & $13.77 \%$ \\
\hline US & $74.70 \%$ & $79.54 \%$ & $67.88 \%$ & $49.14 \%$ & $35.18 \%$ \\
\hline Canada & $56.94 \%$ & $53.79 \%$ & $31.55 \%$ & $15.62 \%$ & $9.94 \%$ \\
\hline Japan & $68.88 \%$ & $84.98 \%$ & $81.27 \%$ & $54.35 \%$ & $37.81 \%$ \\
\hline South Korea & $36.75 \%$ & $41.40 \%$ & $35.74 \%$ & $26.63 \%$ & $18.10 \%$ \\
\hline
\end{tabular}

Notes: The table reports the rankings of the countries according to the DEA methodology for the manufacturing sector. 
Review of Economic Analysis 10 (2018) 97-119

Table 7: Efficiency Scores - ICT Services Sector.

\begin{tabular}{|c|c|c|c|c|c|}
\hline Country & 1999 & 2000 & 2001 & 2002 & 2003 \\
\hline Austria & $70.21 \%$ & $63.40 \%$ & $68.79 \%$ & $72.64 \%$ & $74.49 \%$ \\
\hline Belgium & $100.00 \%$ & $100.00 \%$ & $100.00 \%$ & $100.00 \%$ & $100.00 \%$ \\
\hline Czech & $29.00 \%$ & $35.53 \%$ & $58.08 \%$ & $58.27 \%$ & $49.02 \%$ \\
\hline Denmark & $41.42 \%$ & $38.29 \%$ & $40.52 \%$ & $38.36 \%$ & $36.68 \%$ \\
\hline Estonia & $8.98 \%$ & $14.35 \%$ & $17.17 \%$ & $15.50 \%$ & $16.40 \%$ \\
\hline Finland & $44.93 \%$ & $35.52 \%$ & $36.39 \%$ & $38.10 \%$ & $38.41 \%$ \\
\hline France & $86.52 \%$ & $78.30 \%$ & $74.85 \%$ & $73.98 \%$ & $73.64 \%$ \\
\hline Germany & $83.04 \%$ & $75.85 \%$ & $84.72 \%$ & $85.04 \%$ & $82.35 \%$ \\
\hline Greece & $24.56 \%$ & $29.32 \%$ & $40.05 \%$ & $51.40 \%$ & $64.36 \%$ \\
\hline Hungary & $28.32 \%$ & $26.25 \%$ & $34.89 \%$ & $38.55 \%$ & $33.49 \%$ \\
\hline Ireland & $91.86 \%$ & $100.00 \%$ & $100.00 \%$ & $100.00 \%$ & $100.00 \%$ \\
\hline Italy & $62.89 \%$ & $65.50 \%$ & $72.51 \%$ & $78.42 \%$ & $82.30 \%$ \\
\hline Latvia & $21.51 \%$ & $19.84 \%$ & $25.84 \%$ & $25.92 \%$ & $28.41 \%$ \\
\hline Luxembourg & $100.00 \%$ & $100.00 \%$ & $100.00 \%$ & $100.00 \%$ & $100.00 \%$ \\
\hline Netherlands & $67.18 \%$ & $51.99 \%$ & $54.17 \%$ & $52.31 \%$ & $51.82 \%$ \\
\hline Poland & $100.00 \%$ & $100.00 \%$ & $100.00 \%$ & $100.00 \%$ & $100.00 \%$ \\
\hline Portugal & $42.49 \%$ & $36.66 \%$ & $48.97 \%$ & $54.55 \%$ & $54.81 \%$ \\
\hline Slovakia & $15.84 \%$ & $8.33 \%$ & $7.95 \%$ & $13.79 \%$ & $13.78 \%$ \\
\hline Spain & $53.38 \%$ & $41.39 \%$ & $51.81 \%$ & $49.35 \%$ & $48.39 \%$ \\
\hline Sweden & $44.18 \%$ & $41.48 \%$ & $39.04 \%$ & $40.95 \%$ & $50.42 \%$ \\
\hline UK & $59.07 \%$ & $61.75 \%$ & $64.69 \%$ & $64.67 \%$ & $61.60 \%$ \\
\hline $\mathrm{EU}$ & $55.97 \%$ & $53.51 \%$ & $58.12 \%$ & $59.61 \%$ & $60.02 \%$ \\
\hline Norway & $48.37 \%$ & $48.85 \%$ & $47.49 \%$ & $52.26 \%$ & $46.00 \%$ \\
\hline US & $55.61 \%$ & $60.55 \%$ & $67.53 \%$ & $68.47 \%$ & $61.72 \%$ \\
\hline Canada & $29.93 \%$ & $31.76 \%$ & $31.92 \%$ & $35.84 \%$ & $37.42 \%$ \\
\hline Japan & $46.91 \%$ & $58.03 \%$ & $55.12 \%$ & $52.25 \%$ & $49.61 \%$ \\
\hline South Korea & $25.86 \%$ & $26.48 \%$ & $17.32 \%$ & $21.72 \%$ & $22.72 \%$ \\
\hline
\end{tabular}

Notes: The table reports the rankings of the countries according to the DEA methodology for the ICT services sector.

total service production. High export growth is shown by Poland, Hungary and the Czech Republic. Also, major EU economies, such as France and Germany, perform well. Poor performance is displayed by Greece, which has a negative export growth.

The average EU production efficiency is larger in the services sector than in manufacturing. The intertemporal behaviour of efficiency scores implies that in the latter sector, efficiency 


\section{PSYCHOYIOS AND DOTSIS Competitiveness of the European ICT Industry}

deteriorates whereas in the former, it improves. Nevertheless, in both sectors, the average EU score suggests that it could use a smaller fraction of its resources to attain the same outcome.

In the manufacturing sector, labour productivity per employee has a more significant effect on exports for the other countries in the world, than for the EU countries. A point to be emphasized is that R\&D expenses appear to be negatively related to exports for the EU, whereas for other countries, it has a significantly high positive impact. A plausible explanation of this result is that R\&D expenses in the EU do not generate significant innovation and product quality, at least not in the short term. Given the high competition from the Asia-Pacific countries, this phenomenon should be carefully dealt with.

In the services sector, labour productivity per employee appears to have a significant negative effect on exports in the EU, whereas for the other countries of the world, it has a significant positive effect. This puzzling result is most likely due to the very limited dataset available for the services sector. It might also be produced by the fact that labour productivity is not measured in terms of unit labour cost. EU R\&D expenses appear to have a positive relationship with exports, but to a lesser extent, compared to the other countries sample.

Within the EU, in the manufacturing sector, the Baltic Countries, Estonia, Latvia and Lithuania, display high labour productivity and exports growth, being in a 'catching up' position. However, in terms of efficiency, these countries do not perform well and their dynamics are probably driven initially by low labour costs. Overall, new member states do not perform well, in terms of efficient use of resources ( $R \& D$ and labour) with the exception of Poland that performs efficiently in the services sector and the Czech Republic that performs efficiently in the manufacturing sector.

The large EU economies, France, Italy and Germany, are performing better in the services sector than in manufacturing, where they also appear to use their resources more efficiently. Ireland is a distinct case within the EU and shows consistently high efficiency in both the manufacturing and services sector. Ireland is a global leader in the exports services and accounts for a substantial part of the total EU ICT manufacturing exports.

Appropriate policies should be implemented - especially in the ICT manufacturing sector for making EU more competitive in "non- price factors", such as policies that facilitate the transformation of R\&D expenses into product innovation. Return on investment from R\&D for the EU ICT sector seems to be less than satisfactory, at least with respect to its reflection on competitiveness. There is clearly a lot of space for improvement in the way R\&D is carried out in the ICT sector within the EU, with respect to both the allocation of R\&D investment and the process of producing results from $\mathrm{R} \& \mathrm{D}$.

In terms of economic efficiency, the EU -on average- appears to be making less than optimum use of its resources, in the sense that the same production levels could be attained by efficiently implementing smaller quantities of production inputs. This problem is much worse for the manufacturing industry, where even the large economies of the EU perform poorly. The 
New Member States seem promising in the services and manufacturing sectors, but in these countries the production efficiency should be enhanced.

\section{References}

Anderton, R. (1999). Innovation, product quality, variety, and trade performance: an empirical analysis of Germany and the UK. Oxford Economic Papers, 51, 152-167.

Bartlett, C.A. and Ghoshal, S. (1987). Managing across borders: new strategic requirements. Sloan Management Review, Summer, 7-17.

Bernard, A.B., Branford J., Redding, S.J. and Schott, P.K. (2007). Firms in International Trade. Journal of Economic Perspectives, 21, 105-30.

Blind, K., and Jungmittag, A. (2005). Trade and the Impact of Innovations and Standards: The Case of Germany and the UK. Applied Economics, 37, 1385-1398.

Buckley, P.J., Pass C.L., and Prescott, K. (1988). Measures of International Competitiveness: A Critical Survey. Journal of Marketing Management, 2, 175-200.

Carlin, W., Glyn, A., and Van Reenen, J. (2001). Export Market Performance of OECD countries: An empirical Examination of the cost competitiveness. Economic Journal, 111, , 128-162.

Dahl, C.M., Kongsted, H.C. and Sørense, A. (2011). ICT and productivity growth in the 1990s: panel data evidence on Europe. Empirical Economics, 40, 141-164

Datta D.K., Guthrie J.P., Wright P.M. (2005). Human resource management and labor productivity: Does industry matter? Academy of Management Journal, 48, 135-145.

Delgado, M., Ketels, C., Porter, M.E. and Stern, S. (2012) The Determinants Of National Competitiveness. National Bureau of Economic Research (NBER), Working Paper 18249. http://www.nber.org/papers/w18249

Fagerberg, J. (1988), International competitiveness. Economic Journal , 98, 355-374

Fried, H.O., Lovell, C.A., Schmidt, S.S. (1993) (eds.), The Measurement of Productive Efficiency (Oxford University Press).

Griffith, R., Redding, S. and Van Reenen, J. (2004). Mapping the Two Faces of R\&D: Productivity Growth in a Panel of OECD Industries. The Review of Economics and Statistics, 86, 883-895

Griliches Z. and Mairesse, J. (1984), Productivity and R\&D at the Firm Level, in Griliches Z. (ed.), $R \& D$, Patents and Productivity (University of Chicago Press, Chicago).

$\mathrm{Gu}, \mathrm{W}$. and Ho, M.S. (2000). A Comparison of Industrial Productivity Growth in Canada and the United States. American Economic Review. 90, 172-175.

Halkos, G.E. and Tzeremes, N.G. (2007). International Competitiveness in the ICT Industry: Evaluating the Performance of the Top 50 Companies. Global Economic Review, 36, 167182. 
PSYCHOYIOS AND DOTSIS Competitiveness of the European ICT Industry

Hall, B. H., Lotti, F., and Mairesse, J. (2013). Evidence on the impact of R\&D and ICT investments on innovation and productivity in Italian firms. Economics of Innovation and New Technology, 22, 300-328.

Hall, B.H, and Mairesse, J. (1995). Exploring the relationship between R\&D and productivity in French manufacturing firms. Journal of Econometrics, 65, 263-293.

Ioannidis, E. and P. Schreyer (1997), Technology and non-technology determinants of export share growth, OECD Economic Studies No 28.

Jalava, J. and Pohjola M. (2002). Economic growth in the New Economy: evidence from advanced economies. Information Economics and Policy, 14, 189-210

Jolliffe, I.T. (1986) Principal Components Analysis (New York: Springer-Verlag).

Jorgenson, D.W. and Stiroh, K. J. (1999). Information Technology and Growth. American Economic Review, 89, 109-115

Jorgenson, D.W., Ho M.S. and Stiroh K.J. (2008). A retrospective look at the U.S. productivity growth resurgence. Journal of Economic Perspectives, 22, 3-24

Jung, H.W.H. and Subramanian, A. (2017). CEO talent, CEO compensation, and product market competition. Journal of Financial Economics, forthcoming.

Lee, S., Nam, Y., Lee, S., and Son, H., (2016). Determinants of ICT innovations: A crosscountry empirical study. Technological Forecasting and Social Change, 110, pp 71-77

Matteucci, N., O'Mahony, M., Robinson, C. and Zwick, T. (2005). Productivity, Workplace Performance and ICT: Industry and Firm-Level Evidence for Europe and the US. Scottish Journal of Political Economy, 52, 359-386

O’Mahony M, van Ark B (eds) (2003) EU productivity and competitiveness: an industry perspective. Can Europe resume the catching-up process? Office for Official Publications of the European Communities, Luxembourg.

Pitelis, C.N. (1998). Productivity, Competitiveness and Convergence in the European Economy: Supply-Side Considerations, Contributions to Political Economy, 17, 1-20.

Rouvinen, P. (2002), R\&D-productivity dynamics: Causality, lags and Dry Holes, Journal of Applied Economics, 2002, 123-156.

Schreyer, P., and Pilat, D. (2001), Measuring Productivity, OECD Economic Studies 33, 127165.

Solow, R. M. (1956), A contribution to the theory of economic growth, Quarterly Journal of Economics 70, 65-94.

Temple, J. (1999), The new growth evidence, Journal of Economic Literature, 37, 112-56. 


\section{Appendix A.1. Descriptive Statistics for non-EU countries}

Table 8: Descriptive Statistics for ICT Manufacturing.

\begin{tabular}{|c|c|c|c|c|c|c|c|c|c|}
\hline \multirow[b]{2}{*}{ Countries } & \multicolumn{3}{|c|}{$\begin{array}{c}\text { Labour Productivity } \\
\text { Growth }\end{array}$} & \multicolumn{3}{|c|}{ Exports Growth } & \multicolumn{3}{|c|}{ R\&D expenses Growth } \\
\hline & Mean & STD & $\mathrm{CV}$ & Mean & STD & $\mathrm{CV}$ & Mean & STD & $\mathrm{CV}$ \\
\hline Iceland & 0.0944 & 1.3523 & 14.325 & 0.3180 & 4.9967 & 15.713 & - & - & - \\
\hline Norway & -0.0135 & 0.9252 & -68.533 & 0.0003 & - & $\begin{array}{c}3.988 .40 \\
6\end{array}$ & 0.0444 & 1.9401 & 43.696 \\
\hline $\begin{array}{l}\text { Switzerlan } \\
\text { d }\end{array}$ & 0.0221 & 0.5071 & 22.947 & -0.0305 & 1.5825 & -51.886 & - & - & - \\
\hline Australia & - & - & - & - & - & - & -0.0525 & 1.0112 & -19.260 \\
\hline China & 0.4912 & 0.1308 & 0.2662 & 0.4270 & 0.1698 & 0.3977 & - & - & - \\
\hline Hong Kong & - & - & - & 0.1678 & 2.3713 & 14.132 & - & - & - \\
\hline India & 0.1972 & 4.2416 & 21.509 & 0.5522 & 0.5288 & 0.9576 & - & - & - \\
\hline Japan & 0.3134 & 0.1718 & 0.5481 & 0.0051 & 1.2531 & 245.706 & 0.0181 & 0.2882 & 15.924 \\
\hline Singapore & 0.3520 & 3.6506 & 10.371 & 0.5661 & 11.9068 & 21.033 & - & - & - \\
\hline $\begin{array}{l}\text { South } \\
\text { Korea }\end{array}$ & 0.4354 & 0.1944 & 0.4465 & 0.1047 & 1.9646 & 18.764 & 0.1502 & 0.0473 & 0.3151 \\
\hline Taiwan & 0.4684 & 0.2168 & 0.4628 & 0.0502 & 1.6389 & 32.647 & - & - & - \\
\hline Canada & 0.0463 & 2.6582 & 57.412 & -0.0547 & 3.3354 & -60.977 & 0.0368 & 2.8521 & 77.504 \\
\hline Mexico & 0.2280 & 0.1595 & 0.6997 & 0.1038 & 1.9655 & 18.935 & - & - & - \\
\hline US & 0.2163 & 1.3523 & 11.041 & -0.0111 & 4.9967 & -168.629 & 0.0177 & - & 95.291 \\
\hline
\end{tabular}

Notes: To remove non-stationarities and allow comparisons between countries, we concentrate on growth rates. The statistics are reported for all countries separately and span the period from 2000 to 2004. The descriptive statistics employed, include: mean labour productivity growth, mean exports growth and mean R\&D expenses growth. Standard deviation (STD) and coefficient of variation (CV) for the growth rates are also reported as measures of stability.

Table 9: Descriptive Statistics for ICT Services.

\begin{tabular}{|c|c|c|c|c|c|c|c|c|c|}
\hline \multirow[b]{2}{*}{ Countries } & \multicolumn{3}{|c|}{$\begin{array}{c}\text { Labour Productivity } \\
\text { Growth }\end{array}$} & \multicolumn{3}{|c|}{ Exports Growth } & \multicolumn{3}{|c|}{ R\&D expenses Growth } \\
\hline & Mean & STD & $\mathrm{CV}$ & Mean & STD & $\mathrm{CV}$ & Mean & STD & $\mathrm{CV}$ \\
\hline Iceland & 0.0300 & 1.7250 & 57.500 & 0.1241 & 2.2008 & 17.734 & - & & - \\
\hline Norway & 0.0321 & 0.4294 & 13.377 & 0.0967 & 6.7737 & 70.049 & 0.0816 & 1.0060 & 12.329 \\
\hline Switzerland & 0.0490 & 0.0477 & 0.9725 & - & - & - & - & - & - \\
\hline Australia & - & - & - & 0.1152 & 1.8389 & 15.963 & 0.0314 & 0.5985 & 19.059 \\
\hline China & 0.1793 & 0.0926 & 0.5167 & - & - & - & - & - & - \\
\hline Hong Kong & - & - & - & - & -- & - & - & - & - \\
\hline India & 0.2564 & 0.1245 & 0.4854 & - & - & - & - & - & - \\
\hline Japan & 0.0398 & 0.4811 & 12.089 & -0.0099 & 1.5010 & -151.612 & -0.0715 & 1.3596 & -19.015 \\
\hline Singapore & 0.2108 & 3.2337 & 15.340 & - & - & - & - & & - \\
\hline $\begin{array}{l}\text { South } \\
\text { Korea }\end{array}$ & 0.1403 & 2.8841 & 20.557 & 0.6180 & 6.6596 & 10.776 & 0.3519 & 5.7687 & 16.393 \\
\hline
\end{tabular}


PSYCHOYIOS AND DOTSIS Competitiveness of the European ICT Industry

Table 9 continued.

\begin{tabular}{l|ccc|ccc|ccc}
\hline Taiwan & 0.1087 & 0.0897 & 0.8251 & - & - & - & - & - & - \\
Canada & 0.0819 & 0.0595 & 0.7268 & 0.0033 & 1.0630 & 322.118 & 0.1542 & 2.5886 & 16.787 \\
Mexico & -0.0469 & 1.1299 & -24.091 & - & - & - & - & - & - \\
US & 0.0467 & 0.0305 & 0.6527 & 0.0191 & 0.2928 & 15.330 & 0.1885 & 0.1467 & 0.7783 \\
\hline
\end{tabular}

Notes: To remove non-stationarities and allow comparisons between countries, we concentrate on growth rates. The statistics are reported for all countries separately and span the period from 2000 to 2004. The descriptive statistics employed include: mean labour productivity growth, mean exports growth and mean R\&D expenses growth. Standard deviation (STD) and coefficient of variation $(\mathrm{CV})$ for the growth rates are also reported as measures of stability. 